\title{
Exploring Interaction in Academic Book Reviews across Different Disciplines: A Comparative Study
}

Fatma Ahmed

Ain Shams University-Faculty of Women for Arts, Science and EducationDepartment of English Language and Literature

farouk_fatma@yahoo.com

\begin{abstract}
This study is a corpus-based study that aims at examining the frequencies and the functions of metadiscourse elements based on Hyland's Metadiscourse theory and ideational metafunction elements based on Hallidayan Systemic Functional Grammar theory in the relatively neglected academic genre of the book reviews by using a computer software. The researcher compares between two different disciplines. These disciplines are chemistry and sociology.

In addition to studying the distinctive features of metadiscourse, this study investigates the social relationships that are constructed between the writers and the readers because of using the elements of metadiscourse. Moreover, it investigates the functions that the academic book review writers are trying to perform through their writing which are: organizing their discourse, engaging their readers and conveying their attitude.
\end{abstract}

\section{Keywords}

Corpus Linguistics- Systemic Functional Grammar - Academic book reviewmetadiscourse theory

\section{Aim of the study}

The study aims at examining the frequencies and the purposes of metadiscoure elements and ideational metafunction elements in the relatively neglected academic genre of the book reviews by using a computer software. The researcher compares between the chemistry book reviews which represent the scientific field and the sociology book reviews which represent the social studies field. 
In addition to studying the distinctive features of metadiscourse, this study investigates the social relationships that are constructed between the writers and the readers because of using the elements of metadiscourse. Moreover, it investigates the functions that the academic book review writers are trying to perform through their writing which are: organizing their discourse, engaging their readers and conveying their attitude.

\section{2-Statement of the Problem}

The researcher has chosen to conduct a research on the academic book reviews genre because there is no much research work done by discourse analysts in this area to the researcher's knowledge. The researcher compares between the chemistry book reviews which represent the scientific field and the sociology book reviews which represent the social studies field.

\section{3-Study Questions}

This study tries to find answers to the following questions:

1-What are the most frequent forms of the metadiscourse elements and the ideational metafunction elements used in the genre of book reviews in two different disciplines?

2-What are the functions of the metadiscourse elements and the ideational metafunction elements used in two different academic book reviews disciplines?

3-How do the writers use metadiscourse elements to offer a credible representation of themselves and their work in two different academic book reviews disciplines?

\section{4-Procedure}

The procedures used in the analysis of the collected data are as follows:

\section{1-Stating Hypotheses}

The researcher hypothesizes that the frequencies of the metadiscourse elements and the ideational meta-function elements will differ from one discipline to another. In addition, the researcher hypothesizes that the metadiscourse elements and the ideational meta-function elements are used as persuasion tools.

\section{2- Collection and Selection of Data}


To capture a broad spectrum of academic knowledge, our corpus consists of 80 academic book reviews. These book reviews are divided into 40 chemistry book reviews and 40 sociology book reviews. These academic book reviews are collected from academic international journals.

The publication date for the data under investigation is from 2008 to 2019. These texts are saved as word document files entitled Chemistry Book Reviews and Sociology Book Reviews.

The corpus, as a whole, consists of 72,969 tokens divided as Chemistry Book Reviews (30,476 tokens), and Sociology Book Reviews (42,493tokens).

\section{3-Methodology}

The study attempts a detailed and a comprehensive analysis of the collected data in terms of form and function. The researcher examines the data quantitatively by using antconc 3.4.3 software to determine the frequency of the metadiscourse elements and those of the ideational metafunction elements. The main framework in this study is based on Hyland's Metadiscourse Theory (2005) and Halliday and Matthiessen's Systemic Functional Grammar Theory (2004). These theories have been chosen as a toolkit for conducting the analysis in this study.

Regarding the present study, it adopts the corpus-based approach. The data are collected for a certain aim which is to make a comparison between two different disciplines of academic book reviews. Therefore, corpus linguistics in this study is a methodology that provides certain tools to analyze the selected data quantitatively and qualitatively.

\section{3. - Corpus Analysis is Qualitative and Quantitative:}

Corpus analysis deals with qualitative and quantitative results on equal levels. The researcher gathers large corpora that consist of thousands of words, then he /she uses computer software tools such as keywords, collocations and word lists. In other words, when the researcher gathers his/her corpora, it needs later on to be interpreted and explained, using a computer software which "acts as an aid to the researcher by allowing the linguistic data to be quickly surveyed" (Baker \& McEnery, 2015, p.4).

Then, the qualitative analysis will take place when a certain word or feature appears more frequently than the other words across a corpus, this helps the researcher to understand and analyze the text and the writer's intensions comprehensively. In this study, the researcher is going to apply both the 
qualitative and the quantitative methods, in order to reveal the linguistic characteristics of two different academic book reviews disciplines.

Corpus linguistics then is a method to analyze a given data quantitatively and qualitatively rather than a theory of language or even a separate branch of linguistics such as applied linguistics or sociolinguistics.

\section{5-Review of Literature}

\section{1-Defining Corpus Linguistics}

Corpus linguistics is a branch of linguistics that studies " a finite set of linguistic utterances that serves as an empirical basis for linguistic research" (Bussmann,1996, p.106). Corpus linguistics is different from any other branch of linguistics as it does not represent " a domain of study, but rather a methodological basis for pursuing linguistic research.” (Leech, 1992, p.105).

Corpus linguistics is an analytical method of linguistic analysis which depends on corpora as its primary data for analysis. Kennedy (1998) refers to the field of corpus linguistics as "A scholarly enterprise concerned with the compilation and analysis of corpora" (p.1). Corpus analysis depends on analyzing word lists, concordances, collocations, keywords. This is through statistical form, which leads to accurate results to be analyzed contextually according to the researcher hypothesis. This kind of analysis is quantitative and qualitative, and it depends on the context of situation specially the analysis of concordance.

McEnery (1996) describes corpus linguistics as "the study of language based on examples of real life, language use, nothing that is a methodology rather than an aspect of language requiring explanation or description" (p.1). It has facilitated and modernized the study of language analysis. Hunston (2002) states that corpora, and studying corpora have developed the study of language and of the applications of language. Furthermore, Teubert (2005) describes corpus linguistics as "a theoretical approach to the study of language." (2005, p. 2). Similarly, Nesselhauf (2011) defines corpus linguistics as "a method of carrying out linguistic analysis"

(p. 2).

\section{2-Corpus-Based Versus Corpus-driven}

Tognini- Bonelli (2001) clarifies the differences between Corpus-based studies and corpus-driven studies. Regarding the corpus-based analysis, the corpus is the source of example: which examines the frequency and credibility of any text. 
While in a corpus-driven analysis, the corpus itself is the data and the linguistic patterns are recognized as a way of expressing regularities in the language.

Similarly, Baker el al (2008) explains that " corpus-based analysis tends to focus on what has been explicitly written, rather than what could have been written but was not, or what is implied, inferred, insinuated or latently hinted at" (p. 296 ). Regarding corpus-driven approach, Tognini-Bonelli, (2001) claims that it is a methodology in which the corpus is the basis that identifies the linguistic patterns without any previous expectations. Thus, corpus-driven approach refuses the corpus as a method. Therefore, Corpus-driven linguistics rejects the "characterization of corpus linguistics as a method and claims instead that the corpus itself should be the sole source of our hypotheses about language. It is thus claimed that the corpus itself embodies a theory of language" (TogniniBonelli, 2001, pp. 84-85).

\section{3-Academic Book Review}

Lindholm-Romantschuk (1998) defines the academic book review as "the public evaluations of research, a way of recognizing work done in one's own field, and a vehicle for bringing attention to potentially useful work done in one's own and in other fields" (p.85).

Furthermore, Swales and Feak (2004) states that because book reviews are public and evaluative, writers need to be cautious, and to put into account their readers as well as the strategies they will use when assessing others' works. In other words, the evaluations in book reviews have actual social consequences, making this genre highly interactive.

\section{4- Previous Studies on Academic Book Reviews}

Wiliss (1997) examined the use of hedges in book reviews written in German. He found that hedges were a basic interactive strategy to mitigate criticism.

Abdi (2002) compared the use of interpersonal metadiscourse through "hedges", "emphatics" and "attitude markers" based on a total of 55 academic research articles from social sciences and natural sciences. The analysis revealed that the social science writers have used interpersonal metadiscourse more frequently than the natural science writers.

Shaw (2004) was interested in what he called 'implicit evaluations', or evaluations without specifying an explicit evaluative category. He analyzed a corpus of 
economic book reviews and he found that readers would be able to recognize such implied evaluations because of the fact that evaluations were multiply cued. For example, there is often indication of clause-relations (e.g. but, and, while) to form a relation to reach a clearly marked evaluation and disambiguate the more implicit one, and the polarity of an implicit act can also be inferred from the co-text with the assumption that preceding or following sentences carry the same polarity.

A few studies have compared book reviews in different languages to investigate similarities and differences across different languages. Moreno and Suárez (2008a) have analyzed 40 book reviews in Spanish and English that revealed that frequency and type of criticism mainly depend on language and social factors. They found that literary book reviews in Spanish were less critical and offered more praise than the ones in English. Similarly, Giannoni (2006) compared book reviews in Italian and English. He has provided a detailed qualitative and quantitative analysis to the selected data.

Furthermore, Junqueira (2013) has analyzed 20 applied linguistics book reviews in Brazilian Portuguese and English manually. She noticed that the book reviews in Brazilian and Portuguese were less critical than those in English. Specifically, the last rhetorical move in the book reviews in Brazilian Portuguese always recommend the book under review without mentioning any criticism. Whereas, the book reviews in English recommended the books only after criticizing the books that are being reviewed.

\section{5-Contribution of the present thesis:}

The present study adopts a more quantitative and qualitative methodological approach which allows for the analysis of larger amounts of data. This will lead to more accurate and authentic findings. Moreover, it is important to stress here that the aim of the present study is not to determine which of these academic book reviews disciplines is more critical as in the previous studies, but the aim is to compare between two different book reviews disciplines and to find answers to the following research questions:

1-What are the most frequent forms of the metadiscourse elements and the ideational metafunction elements used in the genre of book reviews in two different disciplines?

2-What are the functions of the metadiscourse elements and the ideational metafunction elements used in two different academic book reviews disciplines? 
3-How do the writers use metadiscourse elements to offer a credible representation of themselves and their work in two different academic book reviews disciplines?

\section{6-Metadiscourse}

Hyland (2005) clarifies that academic discourse is the argumentative language by which a writer tries to achieve three functions at the same time: to organize his discourse, to engage his readers and to express his opinions. These three functions are achieved by what is termed as 'metadiscourse'. The concept of metadiscourse shows clearly that writing is a social process.

\section{7-The Interactive and the Interactional Dimensions of Metadiscourse}

Hyland (2005) introduces his own classification of metadiscourse. He argues that the writer resorts to either interactive or interactional elements according to his purposes and decisions in the different stages of discourse. In other words, a writer's choice of an interactive or an interactional element is dependent on the function it performs in a certain context.

Hyland (2005) explains that the interactive elements are mainly concerned with organizing a text to meet the readers' needs and expectations of the development of a text.

The interactional elements establish a relationship with readers to involve them collaboratively.

The interactional dimension of metadiscourse focuses on building a writer's credibility and building a relationship between the writer and the reader. The interactional features of metadiscourse create a 'communicative space' for readers, and it helps to decide the nature of the relationship between the writer and his reader.

Hyland (2005,p.163) stresses that " interactional metadiscourse tends to be a feature of overtly argumentative and persuasive genre", so writers use the interactional features to persuade the readers with their point of view. These two goals can be achieved through the use of interactional resources like: hedges, boosters, attitude markers, self - mention and engagement markers.

\section{8-Systemic Functional Linguistics}


In fact, language is essential for making sense of our own experience and acting out our social relationships. Its fundamental function is to express human experience, but this has no significance for the analysis of language itself.

Halliday \& Hasan (1976) mention that a text is "a process in the sense of a continuous process of semantic choice, a movement through the network of meaning potential, with each set of choices constituting the environment for a further set" (p. 10). Thus, the text is a process not a product.

Similarly, Halliday and Matthiessen (2014) claim that "systemic analysis shows that functionality is intrinsic to language: that is to say, the entire architecture of language is arranged along with functional lines" (p.30).

\section{9-Grammatical Features of Ideational Metafunction:}

In order to explore the ideational metafunction we have to look for the transitivity system.

\section{Transitivity}

The system of transitivity consists of different process types, participants and circumstances. According to Halliday and Matthiessen (2004), "there are six process types : material process, behaviour process, mental process, verbal process, relational process, and existential process"(p. 173). Halliday and Matthiessen (2004) explain that material process is the process of doing things; express notion that some entity 'does' something, which may be done to some other entity. Behavioral process is the process of physiological and psychological behaviour such as breathing, crying, drinking. Mental process is a kind of activity in people's mind, requires a conscious participant such as thinking, loving, wanting, hearing. Verbal process is the process of saying such as saying, telling, speaking, talking. Relational process is the process of 'being', 'having' and 'being at' in form of three subtypes: the intensive, the possessive, and the circumstantial. Existential process is the process of existing, indicating that something or some natural force exists.

\section{6-Analysis}

\section{1- The Ideational Dimension}

The following part provides an analysis of the verbs and their process types within the top 50 words provided by AntConc software describing the whole corpus. 
Throughout the top 50 words. It is noticed that the writers of sociology book reviews use verb to be "is" 649 times and appears at rank (7), verb "are" is used 307 times and appears at rank (11), verb to "be" is used 206 times and appears at rank (17), , verb to have "have" is used "191" and appears at rank (20), verb "has" is used 123 times and appears at rank (34). As for chemistry book reviews, it is noticed that the writers of chemistry book reviews use verb to be "is" 554 times and appears at rank (7), verb "are" is used 336 times and appears at rank (12), verb to "be" is used 237 times and appears at rank (20), verb to have " have" is used "126" and appears at rank (32), verb "has" is used 106 times and appears at rank (40).

The investigation of the two corpora of different disciplines reveals the fact that relational processes are the most frequent processes among other processes. Concerning relational processes, they are mainly represented by " verb to be" and "verb to have". Furthermore, "verb to be" is the most frequent marker of all markers in the ideational dimension.

Through the present study, it has been noticed that there are two main functions of the relational processes. First, they are used in connection with adjectives to give positive or negative connotations. Second, they are used to reclassify relations between entities with the aim of steering readers' interpretations to a certain direction. These positive or negative connotations are used to express the book reviewer writers' opinions about the different books they are reviewing. For example:

- This chapter is an excellent addition to the text, focusing on one of the most contentious movements in the current Canadian context. (Concordance hit 188, Sociology book reviews).

- Third, the chapter that lists points for final considerations is useful as a summary of what the book intends to call for, but the persistent dichotomy between tangible and intangible heritage dampens the core critique of place heritage understanding. (Concordance hit 129, Chemistry book reviews).

\section{2-The Interactive Dimension}

According to Hyland (2005), the interactive dimension is mainly concerned with organizing the writer's argument in a logical consequence. This logical consequence 
directs readers to the direction the writer intends by his argument. Writers use four types of markers: Transition, Endophoric, Frame markers and Code glosses.

The table below shows the frequency of each type of the interactive markers in the collected data.

\begin{tabular}{|l|l|l|}
\hline & Sociology & Chemistry \\
\hline Transition Markers & 2091 & 1576 \\
\hline Frame Markers & 411 & 332 \\
\hline Code Glosses & 198 & 107 \\
\hline Endophoric Markers & 143 & 87 \\
\hline Total & 2910 & 2155 \\
\hline
\end{tabular}

Table (1) Frequencies of the interactive markers in the collected data

\subsection{1- Transition Markers}

According to Hyland (2005), transition marker is a step by step interpretive scheme used by a writer to guide his readers to a specific interpretation. Transition markers can be used in three ways to relate different steps of an argument: comparison, consequence and addition. It is evident from table (1) that the transition markers come in the first rank in both disciplines. The total frequency of transition markers in the discipline of sociology is ( 2091 ) that represents $71.8 \%$ and (1576) that represents $73.1 \%$ in the discipline of chemistry.

For example:

- This edited volume explores the issue of methodological nationalism and perspectives on this concept as conceived by the founders of sociology.." (Concordance hit 606, Sociology book reviews).

- Chapters 10 to 12 deal with air, noise and water pollution respectively. Each topic separately emphasizes the cause, effect and control measures for bringing down pollution.. (Concordance hits 14-15, Chemistry book reviews). 
Through the investigation of the two different corpora of the sociology and chemistry disciplines, transition markers are used to achieve two functions. First, they direct readers' interpretation to reach certain conclusions. Second, they are used to relate different parts of argument to be perceived as coherent and cohesive. Consequently, they establish cohesive relations between the different parts of the argument to be realized as one unified whole.

\subsection{2- Frame Markers}

Hyland (2005) mentions that frame markers are devices which " signal text boundaries or elements of schematic text structure" (p.51). The role of frame markers is to announce a writer's goals and this can be exemplified in markers like: my focus, my aim, my purpose, and I seek to.

It can be noticed from table (1) that the frame markers come in the second rank in both disciplines. The total frequency of frame markers in the discipline of sociology is (411) and (332) in the discipline of chemistry.

Through studying the two corpora accurately, frame markers are used to specify the overall organization of an argument. First, book reviewers in both disciplines use frame markers to organize their main claim using sequencers such as: first, second and third. Second, frame markers are used in both disciplines to announce goals. Third, frame markers are used in both disciplines to shift the topics. Fourth, frame markers are used in both disciplines to label stages. For example:

- First, Andrews returns to her research on lifelong socialist activists in England, who, in their eighties, reflect on what sustained their socialist perspectives and activities throughout their lives. (Concordance hits 1516, Sociology book reviews).

- The second chapter, covers the physical and chemical basis of color. (Concordance hit 33, Chemistry book reviews)

\subsection{3- Code glosses}

Crismore et al (1993) define code glosses as expressions which " provide additional information or examples for words or propositions that the writer predicts the reader may find problematic" (p.49). Code glosses are tools that provide readers with further information to ensure their understanding of a writer's intended meaning. 
It is clear from table (1) that code glosses come in the third rank in both disciplines with a total frequency of (198) in the discipline of sociology with the percentage of $6.8 \%$ and a total frequency of (107) with the percentage of $4.9 \%$ in the discipline of chemistry.

Throughout the present study, code glosses are used to convey a main function. They are used to give extra explanation for readers to contribute to the clarity of writers' message. In other words, code glosses markers play a major role in the interpretation of the writers' intended message. For Example

- For example, he points out that Snowden did not want anonymity - but, he did flee the US and seek asylum in other countries. (Concordance hit 41,Sociology book reviews).

- For instance, in the introductory paragraph to the section on radioactive substances, scientific notation is used to compare the Curie, picocurie, and Becquerel. (Concordance hit 2, Chemistry book reviews).

\subsection{4- Endophoric markers}

Hyland (2005) defines endophoric markers as devices that " refer the reader to explanatory or related material elsewhere in the text. They represent the writer's assessment of both material and the audience, relating the propositions of the reader's assumed ability to process, and accept, the ongoing argument" (p.156). Endophoric markers can be explained as linguistic items used to refer to other portion of discourse cataphorically (forward) or anaphorically ( backward).

As for the endophoric markers, they come in the fourth rank in respect to frequency in both disciplines with a total frequency of (143) in the discipline of sociology that represents $4.9 \%$ and a total frequency of (87) that represents $4.03 \%$ in the discipline of chemistry.

Throughout the collected data, endophoric markers are used to relate different parts of the book reviews so as to make the content clearer.

In fact, writers deploy endophoric markers to realize two functions. First, endophoric markers are used to unify the different parts of an argument as one unit. Second, endophoric markers are used to relate remote information to the immediate point of discourse to reinforce the writer's argument, and steer the readers to a certain interpretation. For example: 
- It also "provides a structure for the affects of anxiety, despair, indignation, hope, anticipation, and elation, and weds them to a selective existential picture of the world" (p. 89). (Concordance hit 90, Sociology book reviews).

- For example, after explaining that greenhouse gases act as insulators, Beard compares an increase in the concentration of greenhouse gases to "putting more blankets on one's beds" (p 226).. (Concordance hits 39, Chemistry book reviews).

\section{3-The Interactional Dimension}

According to Hyland (2005), the interactional dimension is mainly concerned with establishing a relationship between writers and their own readers. The interactional dimension is encoded by five types of markers: hedges. engagement markers, boosters, attitude markers and self-mention.

A close investigation of the collected data reveals the fact that attitude markers are the most frequent. The following table shows the frequency of each type of the interactional markers in the collected data.

\begin{tabular}{|l|l|l|}
\hline & Sociology & Chemistry \\
\hline Attitude Markers & 595 & 407 \\
\hline Self Mention & 229 & 230 \\
\hline Engagement Markers & 224 & 205 \\
\hline Hedges & 154 & 146 \\
\hline Boosters & 88 & 70 \\
\hline Total & 1290 & 1058 \\
\hline
\end{tabular}

Table (2) Frequencies of the interactional markers in the collected data

\subsection{1-Attitude markers}

Hyland (2005) clarifies that attitude markers are used to express the writer's stance throughout a text. They are usually conveyed through attitude verbs (e.g: disagree, agree), sentential adverbs (e.g. surprisingly, ) and adjectives ( remarkable, logical). 
According to table (2), attitude markers come in the first rank with respect to other markers with a total frequency of (595) in the discipline of sociology that represents $46.1 \%$ and a total frequency of (407) in the discipline of chemistry that represents $38.4 \%$.

Throughout the whole corpus of both disciplines attitude markers are used to achieve three functions. First, attitude markers are used to clarify the book reviewers' reaction to the authors' claims. Second, they are used to assess the authors' claims. Third, they are used to comment on various claims. These functions are evident in the following examples:

- Acknowledging the institutional racism and monitoring racist incidents are surely important suggestions, but their effectiveness remains debatable since they are similar to previously existing measures that are criticized in this book. (Concordance hit 13, Sociology book reviews).

- In addition, the absence of end-of-chapter problems or exercises will pose a challenge to an instructor using this textbook. Curiously, the authors list secondary sources almost exclusively. (Concordance hits 10-11-12, Chemistry book reviews).

\subsection{2-Self -mention}

Self - mention refers to the writer's explicit reference in himself using first person pronouns and possessive adjectives (e.g. I, we, our, our, me, mine). Hyland (2005) highlights that "the first person pronouns is perhaps the most powerful means of self representation.....The presence or absence of explicit author reference is generally a conscious choice by writers to adopt a particular stance and a contextually situated authorial identity" (p.53). Thus, a writer chooses to use self mention pronouns to achieve certain functions.

According to table (2), attitude markers come in the second rank with respect to other markers with a total frequency of (229) in the discipline of sociology with the percentage of $17.7 \%$ and a total frequency of (230) in the discipline of chemistry with the percentage of $21.7 \%$. Throughout the collected data, self - mention markers are used to personalize claims. Self - mention markers' function in both book reviews disciplines is to establish a main claim and represent personal opinions and evaluations about the books under review. For Example:

- It is impossible to do justice here to more than a sprinkling of his observations. I will focus briefly on Smelser's views on ideology. (Concordance hit 4, Sociology book reviews). 
- I really enjoyed reading the book and must admit that I discovered several interesting aspects that I haven't been aware of. (Concordance hits 5-6-7, Chemistry book reviews).

\subsection{3-Engagement Markers}

Hyland (2005) explains that engagement markers represent writers' choice to indicate their readers directly as discourse participants. They are used to focus readers' attention and direct them in a certain way. The writer's expectations of his readers' needs decide the sort of guidance they need and where to present this guidance.

As it is clear from table (2), engagement markers come in the third rank in both disciplines with respect to other markers with a total frequency of (224) that represents $17.3 \%$ in the discipline of sociology and a total frequency of (205) that represents $19.3 \%$ in the discipline of chemistry.

Writers of academic book reviews of both disciplines use engagement markers to open channels of communication with their readers, so they can represent their claims and opinions easily.

For example:

- Andrews's book may be of limited use to those interested in nationalism, collective identity, collective memory, and social movements, as the reader will not find many new ideas in these areas. (Concordance hits1112, Sociology book reviews).

- While this chapter covers some important foundational material, I suspect that it will intimidate and possibly deter its intended audience. (Concordance hits 9-10, Chemistry book reviews).

\subsection{4-Hedges}

Hyland (2005) explains that hedges are regarded as the linguistic devices which reflect a writer's subjectivity in presenting a claim. Hedges express a writer's claim as an opinion rather than a fact. In fact, hedges are one of the best linguistic tools to start a dialogue with readers.

As it is evident from table (2) above, hedges come in the fourth rank with a total frequency of (154) with the percentage of $11.9 \%$ in the discipline of sociology and a total frequency of (146 ) with the percentage of $13.7 \%$ in the discipline of chemistry. Throughout the collected data, hedges are used to achieve two functions. 
First, they are used to present claims as opinions or suggestions rather than facts. Second, they are used to reflect writers' limitations of knowledge. For Example:

- But the form of expression that some authors opt for in this text will, in my opinion, limit it in developing a wider readership. (Concordance hit 5, Sociology book reviews).

- The next four chapters are, in my opinion, the heart of the book. In these chapters, the various mobile phase approaches (reversed phase, normal phase, and gradient elution) are discussed in a great degree of detail. (Concordance hit 3, Chemistry book reviews).

\subsection{5-Boosters}

Hyland (2005) clarifies that boosters are one of the linguistic tools used by writers to express their certainty and full commitment to a proposition. According to table (2), boosters come in the fifth rank with a total frequency of (88) that represents $6.8 \%$ in the discipline of sociology and a total frequency of (70) that represents $6.6 \%$ in the discipline of chemistry.

It can be noticed throughout the collected data of both disciplines that boosters are used to achieve two functions. First, boosters are used to express the writers' full commitment to their claims especially in opposing others' claims. Second, they are used to eliminate all possible objections that may be raised by readers. The following examples affirm these functions:

- Acknowledging the institutional racism and monitoring racist incidents are surely important suggestions. (Concordance hit 3, Sociology book reviews).

- In summary, the renowned reputation of the previous editions of Loudon's Organic Chemistry is clearly preserved in this newest edition of the book. (Concordance hit 14, Chemistry book reviews).

\section{7-Conclusion}

To sum up, the close investigation of the two corpora of different book reviews disciplines reveals a number of points that answer all the research questions which are: 
1-What are the most frequent forms of the metadiscourse and the ideational metafunction elements used in the genre of book reviews in two different disciplines?

2-What are the functions of the metadiscourse elements and the ideational metafunction elements used in two different academic book reviews disciplines?

3-How do the writers use metadiscourse elements to offer a credible representation of themselves and their work in two different academic book reviews disciplines?

Concerning the ideational dimension, the study reveals that relational processes can be seen as a distinctive feature of the two different academic book reviews disciplines . It can be noticed from the present study that "verb to be" is the most frequent form used to convey transitivity system in the disciplines of sociology and chemistry.

Regarding the high frequency of the relational processes, it can be explained by the nature of the collected data. In its essence, academic discourse is argumentative. This argumentative nature pushes discourse into the direction of readers' persuasion through building new relations between entities in a convincing way. In this context, relational processes are one of the main instruments to convince readers.

Concerning the interactive dimension of metadiscourse, it is evident that transition markers represent a second distinctive feature of academic book reviews of both sociology and chemistry disciplines because they come in the first rank among the interactive elements of metadiscourse in these disciplines.

Transition markers are used to achieve two functions in both disciplines. First, they direct readers' interpretation to reach certain conclusions. Second, they are used to relate different parts of argument to be perceived as coherent and cohesive. Consequently, they establish cohesive relations between the different parts of the argument to be realized as one unified whole.

With respect to frame markers, they come in the second rank in both disciplines Frame markers are used to specify the overall organization of an argument. First, book reviewers in both disciplines use frame markers to organize their main claim using sequencers such as: first, second and third. Second, frame markers are used in both disciplines to announce goals. Third, frame markers are used in both 
disciplines to shift the topics. Fourth, frame markers are used in both disciplines to label stages.

Code glosses come in the third rank in both disciplines. Throughout the present study, code glosses are used to convey a main function in both disciplines. They are used to give extra explanation for readers to contribute to the clarity of writers' message. In other words, code glosses markers play a major role in the interpretation of the writers' intended message.

Regarding endophoric markers, they come in the fourth rank in respect to frequency in both disciplines. Endophoric markers are used to relate different parts of the book reviews so as to make the content clearer. In fact, writers deploy endophoric markers to realize two functions in both disciplines. First, endophoric markers are used to unify the different parts of an argument as one unit. Second, endophoric markers are used to relate remote information to the immediate point of discourse to reinforce the writer's argument, and steer the readers to a certain interpretation.

Concerning the interactional dimension of metadiscourse, it is evident that attitude markers represent a third distinctive feature of academic book reviews of both sociology and chemistry disciplines because they come in the first rank among the interactional elements of metadiscourse in these two different disciplines. In addition, they are used to clarify the book reviewers' reaction to the authors' claims. Second, they are used to assess the authors' claims. Third, they are used to comment on various claims.

Self - mention markers come in the second rank with respect to other interactional metadiscourse markers in both disciplines. Throughout the collected data, self mention markers are used to personalize claims. Self - mention markers' function in both book reviews disciplines is to establish a main claim and represent personal opinions and evaluations about the books under review.

Engagement markers come in the third rank in both disciplines. Writers of academic book reviews of both disciplines use engagement markers to open channels of communication with their readers, so they can represent their claims and opinions easily.

Hedges come in the fourth rank in both disciplines. Throughout the collected data, hedges are used to achieve two functions. First, they are used to present claims as opinions or suggestions rather than facts. Second, they are used to reflect writers' limitations of knowledge. 
Boosters come in the fifth rank in both disciplines. It can be noticed throughout the collected data of both disciplines that boosters are used to achieve two functions. First, boosters are used to express the writers' full commitment to their claims especially in opposing others' claims. Second, they are used to eliminate all possible objections that may be raised by readers.

\section{References}

\section{Primary Sources}

Abu-Baker, S. (2014). Review of Fundamentals of Environmental and Toxicological Chemistry: Sustainable Science, $4^{\text {th }}$ Edition. Journal of Chemical Education, 91(11), 1760-1761.

Abu-Baker, S. (2015). Review of Biochemistry: Concepts and Connections, First Edition. Journal of Chemical Education, 92(12), 1977-1978.

Afanasiev, P. (20 4). Elemental Sulfur and Sulfur-Rich Compounds II. Topics in Current Chemistry: Book Review. Journal of the American Chemical Society, 126(8).

Alekseevskaia, M. (2016). Losing Our Religion: How Unaffiliated Parents are Raising Their Children. The Canadian Journal of Sociology, 41(4), 557 560 .

Anais, S. (2013). Borders and Crime: Pre-Crime, Mobility and Serious Harm in an Age of Globalization. The Canadian Journal of Sociology, 38(1), 104107.

Andrews, S. (2014). Review of The Chlorine Revolution: Water Disinfection and the Fight to Save Lives. Journal of Chemical Education, 91(4), 466-467.

Andrews, S. (2016). Review of ChemConnections Activity Workbook. Journal of Chemical Education, 93(6), 992-993 .

Arora, P. S., \& Canary, J. W. (2013). Organic Chemistry: Principles in Context. A Story Telling Historical Approach:Book Review. Journal of Organic Chemistry, 25(9), 582-582. 
Baehr, P. (2010). Geography of Hope: Exile, the Enlightenment, Disassimilation. The Canadian Journal of Sociology, 35(1), 159-161.

Belford, R. E. (2014). Review of Chemical Information for Chemists: A Primer. Journal of Chemical Education, 91(10), 1515-1516.

Belford, R. E. (2016). Review of Molecules That Amaze Us. Journal of Chemical Education, 93(4), 589-590.

Bevan, J. (2019). Automating Inequality. The Canadian Journal of Sociology, 45(1), 91 - 94.

Boesdorfer, S. B. (2013). Review of Teaching Chemistry-A Studybook: A Practical Guide and Textbook for Student Teachers, Teacher Trainees and Teachers. Journal of Chemical Education, 90(5), 532-533.

Boesdorfer, S. B. (2015). Review of Chemistry Education: Best Practices, Opportunities and Trends. Journal of Chemical Education, 92(12), 19751976.

Boesdorfer, S. B. (2016). Review of Teaching and Learning STEM: A Practical Guide. Journal of Chemical Education, 93(10), 1682-1683.

Boswell, P. G. (2013). Review of Temperature-Programmed Gas Chromatography. Journal of Chemical Education, 90(12), 1585.

Brent, R. (2010). Organizing Urban America: Secular and Faith-based Progressive Movements. The Canadian Journal of Sociology, 35(4), 687688.

Brent, R. (2012). Alliances: Re/Envisioning Indigenous-non-Indigenous Relationships. The Canadian Journal of Sociology, 37(1), 102-104.

Buntrock, R. E. (2012,). Review of Heterocyclic Chemistry, $5^{\text {th }}$ Edition. Journal of Chemical Education , 89(11), 1349-1350.

Buntrock, R. E. (2015). Review of In Retrospect: From the Pill to the Pen. Journal of Chemical Education, 92(5), 785-787.

Buntrock, R. E. (2015). Review of Molecules: The Elements and the Architecture of Everything. Journal of Chemical Education, 92(2), 203-204.

Buntrock, R. E. (2016). Review of Colour Chemistry, $2^{\text {nd }}$ Edition. Journal of Chemical Education, 93(10), 1684-1685. 
Buntrock, R. E. (2016). Review of Early Responses to the Periodic System. Journal of Chemical Education, 93(6), 991.

Buntrock, R. E. (2016). Review of Science and Art: The Painted Surface. Journal of Chemical Education, 93(5), 810.

Burfoot, A. J. (2009). Magnetic Appeal: MRI and the Myth of Transparency. Canadian Journal of Sociology, 34(2), 549-550.

Butler, J. K. (2014). Review of Chemistry of High-Energy Materials, $2^{\text {nd }}$ Edition. Journal of Chemical Education, 91(2), 163-164.

Carlson, J. (2009). Sketch for a Self-Analysis. The Canadian Journal of Sociology, 34(2), 470-473.

Caron, C. (2014). School Rules: Obedience, Discipline, and Elusive Democracy. Canadian Journal of Sociology, 39(2), 303 - 306.

Cederquist, K. B. (2013). Review of Materials Science of DNA. Journal of Chemical Education, 90(4), 408.

Conover, W. (2015). Review of Laboratory Techniques in Organic Chemistry: Supporting Inquiry-Driven Experiments, $4^{\text {th }}$ Edition. Journal of Chemical Education, 92(9), 1433-1434.

Conover, W. (2015). Review of Up from Generality: How Inorganic Chemistry Finally Became a Respectable Field. Journal of Chemical Education , 92(6), 971-972.

Conway, J. (2010). Making Transnational Feminism: Rural Women, NGO Activists, and Northern Donors in Brazil. The Canadian Journal of Sociology, 35(2), 351-353.

Côté, J.-F. (2013). American Mythologies. Semiological Sketches. Canadian Journal of Sociology, 38(1), 90-92.

Dakessian, A. (2014). Global Creative Industries. The Canadian Journal of Sociology, 39(1), 117 - 119.

Datta, R. P. (2016). The Marx Machine: Politics, Polemics, Ideology. Canadian Journal of Sociology, 41(2), 245 - 248. 
DeKorver, B. K. (2014). Review of Trajectories of Chemistry Education Innovation and Reform. Journal of Chemical Education , 91(12), 20182019.

Elisa, D. S. (2015). The Chemistry of Metal Phenolates: Book Review. Applied Organometallic Chemistry, 29(11), 785-786.

Francis, M. (2013). Where the Waters Divide: Neoliberalism, White Privilege, and Environmental Racism in Canada. Canadian Journal of Sociology, 38(1), 87-89.

Gordon, C. E. (2012). Ageing Populations in Post-Industrial Democracies: Comparative Studies of Policies and Politics. Canadian Journal of Sociology, 37(2), 208-212.

Goyder, J. (2010). Social Status and Cultural Consumption. The Canadian Journal of Sociology, 35(4), 659-661.

Grills, S. (2008). The Affective Turn: Theorizing the Social by Patricia Clough with Jean Halley. Canadian Journal of Sociology, 33(1), 189-191.

Gross, M. (2011). The Aquaculture Controversy in Canada: Activism, Policy, and Contested Science. Canadian Journal of Sociology, 36(1), 121-123.

Harris, H. H. (2012). Review of Essentials of Chemical Education. Journal of Chemical Education, 89(11), 1347-1348.

Harris, H. H. (2013). Review of Physical Chemistry for the Life Sciences, $2^{\text {nd }}$ Edition. Journal of Chemical Education, 90(8), 958-959.

Harris, H. H. (2014). Review of The Physical Chemist's Toolbox. Journal of Chemical Education, 91(8), 1101-1102.

Harris, H. H. (2015). Review of Chemical Energy Storage. Journal of Chemical Education, 92(11), 1781.

Hart, R. (2008). Shaping History: Narratives of Political Change. The Canadian Journal of Sociology, 33(1), 195-197.

Haugaard, M. (2009). Culture and Conflict in the Middle East. Canadian Journal of Sociology, 34(2), 483-485. 
Hayes, M. (2014). The Outsourced Self: What Happens When We Pay Others to Live Our Lives for Us. The Canadian Journal of Sociology, 39(1), 127 129.

Holme, T. A. (2014). Review of Pioneers of Quantum Chemistry. Journal of Chemical Education, 91(6), 773-775.

Houghtaling, M. K. (2009). Gender: Key Concepts. The Canadian Journal of Sociology, 34(3), 944-946.

Inglis, P. (2008). Busier Than Ever! Why American Families Can't Slow Down. The Canadian Journal of Sociology, 33(1), 228-230.

Jacobs, M. B. (2015). Review of How Glass Changed the World: The History and Chemistry of Glass from Antiquity to the $13^{\text {th }}$ Century. Journal of Chemical Education, 92(3), 406-407.

Jacobs, M. B. (2016). Review of Top Drugs: Their History, Pharmacology, and Syntheses. Journal of Chemical Education , 93(7), 1171-1172.

James, R. E. (2013). Review of Water Chemistry: Green Science and Technology of Nature's Most Renewable Resource. Journal of Chemical Education , 90(6), 681-682.

Kauffman, G. B. (2012). Review of Symmetry through the Eyes of a Chemist, $3^{\text {rd }}$ Edition. Journal of Chemical Education, 89(9), 1102-1103.

Kay, F. (2010). Perceptions in Litigation and Mediation: Lawyers, Defendants, Plaintiffs and Gendered Parties. The Canadian Journal of Sociology, 35(3), 514-517.

Kelly, B. C. (2010). Successful Societies: How Institutions and Culture Affect Health. Canadian Journal of Sociology, 35(1), 179-181.

Kelly, K. (2008). Rethinking Domestic Violence. The Canadian Journal of Sociology, 33(1), 194-195.

Kevin Walby \& Justin Piché. (2012). Thinking through Tourism. The Canadian Journal of Sociology, 37(4), 457-459.

Kevin, R. (2011). Chemistry of the Solar System . Meteoritics \& Planetary Science, 46(9), 1425 - 1426. 
Kirchhoff, M. M. (2013). Review of Green Organic Chemistry in Lecture and Laboratory. Journal of Chemical Education, 90(6), 683-684.

Koc, M. (2012). Globalization of Food. The Canadian Journal of Sociology, $37(2), 213-216$.

Kopinak, K. (2011). Consuming Mexican Labor: From the Bracero Program to NAFTA. The Canadian Journal of Sociology, 36(4), 411-413.

Kovac, J. (2016). Review of Planck: Driven by Vision, Broken by War. Journal of Chemical Education, 93(7), 1170.

Kovac, J. (2016). Review of The Chemists' War: 1914-1918. Journal of Chemical Education, 93(5), 808-809.

Kuyvenhoven, C. E. (2013). Reinventing Evidence in Social Inquiry: Decoding Facts and Variables. The Canadian Journal of Sociology, 38(2), 292-294.

Lindsay, S. (2010). Making Life Work: Freedom and Disability in a Community Group Home. The Canadian Journal of Sociology, 35(4), 662-663.

Lucken, K. R. (2009). A World Survey of Religion and the State. The Canadian Journal of Sociology, 34(2), 489-491.

Mark CJ Stoddart \& Laura MacDonald. (2011). "Keep it Wild, Keep it Local”: Comparing News Media and the Internet as Sites for Environmental Movement Activism for Jumbo Pass, British Columbia. The Canadian Journal of Sociology, 36(4), 313-335.

Mascarenhas, C. M. (2014). Review of Advances in Teaching Organic Chemistry. Journal of Chemical Education, 91(4), 468-469.

Mascarenhas, C. M. (2014). Review of Developing and Maintaining a Successful Undergraduate Research Program. Journal of Chemical Education, 91(12), 2020-2021.

McCoy, L. (2013). Visual Sociology. The Canadian Journal of Sociology, 38(2), 277-279.

McDaniel, S. (2013). Generation, Discourse, and Social Change. The Canadian Journal of Sociology, 38(3), 444-446.

McKinnon, A. (2010). The Promise of Salvation: A Theory of Religion. The Canadian Journal of Sociology, 35(3), 470-473. 
Mowbray, M. (2012). Making the Scene: Yorkville and Hip Toronto in the 1960s. The Canadian Journal of Sociology, 37(3), 337-341.

Myers, D. R. (2016). Review of Organic Mechanisms: Reactions, Methodology, and Biological Applications. Journal of Chemical Education , 93(2), 225226.

Osborne, G. B. (2012). Writing Ethnographic Fieldnotes. The Canadian Journal of Sociology, 37(2), 197-199.

Ritzer, G. (2008). Deadly Worlds: The Emotional Costs of Globalization. The Canadian Journal of Sociology, 33(1), 187-189.

Robert E. Buntrock \& Jason Bolton. (2014). Review of The Chemistry of Beer. Journal of Chemical Education, 91(10), 1511-1512.

Valerie Sarah \& Elizabeth Zawilski. (2012). The Russian Quest for Peace and Democracy. The Canadian Journal of Sociology, 37(1), 96-97.

\section{Secondary Sources}

Abdi, R. (2002). Interpersonal Metadiscourse: An Indicator of Interaction and Identity. Discourse Studies, 4(2), 139-145.

Baker, P., \& McEnery, A. (Eds.). (2015). Corpora and Discourse Studies: Integrating Discourse and Corpora. London, UK: Palgrave Macmillan.

Baker, P., Gabrielatos, C., Khosravinik, M., Krzyżanowski, M., McEnery, T., \& Wodak, R. (2008). A Useful Methodological Synergy? Combining Critical Discourse Analysis and Corpus Linguistics to Examine Discourses of Refugees and Asylum Seekers in the UK Press. Discourse \& Society, 19(3), 273-306.

Bussmann, H. T. (1996). Routledge dictionary of language and linguistics. London: Routledge.

Crismore, A. Markkanen , R. \& Steffensen, M. (1993). Metadiscourse in Persuasive Writing:A Study of Texts Written by American and Finnish University Students. Written Communication, 10(1), 39-71.

Giannoni, D. (2006). Expressing Praise and Criticism in Economic Discourse: A Comparative Analysis of English/Italian Book Reviews. In G. Del Lungo 
Camiciotti, M. Dossena \& B. Crawford Camiciottoli (Eds.). Variation in Business and Economics Discourse: Diachronic and Genre Perspectives, 126-138.

Halliday, M. A. K, \& Matthiessen, C. M. (2004). An Introduction to Functional Grammar . London: Arnold.

Halliday, M. A. K. \& Hasan, R. (1976). Cohesion in English. London: Longman. Halliday, M. A. K., \& Matthiessen, C. M . (2014). Halliday's Introduction to Functional Grammar (3rd ed). London / New York: Routledge.

Hunston, S. (2002). Corpora in Applied Linguistics. Cambridge University Press. Hyland, K. (2005). Metadiscourse: Exploring Interaction in Writing. New York: Continuum.

Junqueira, L. (2013). A Genre-based Investigation of Applied Linguistics Book Reviews in English and Brazilian Portuguese. Journal of English for Academic Purposes, 12(3), 203-213.

Kennedy, G. (1998). An Introduction to Corpus Linguistics. London: Longman.

Leech, G. (1992). Corpus linguistics and theories of linguistic performance. In Svartvik, J. (ed.). Directions in Corpus Linguistics: Proceedings of Nobel Symposium 82, 105-128.

Lindholm-Romantschuk, Y. (1998). Scholarly book reviewing in the social sciences and humanities. London: Greenwood Press.

McEnery, A. A. (1996). Corpus Linguistics. (W. A., Ed.). Edinburg: Edinburg University Press.

Moreno, A. I. \& Suárez, L. (2008a). A Study of Critical Attitude across English and Spanish Academic Book Reviews. Journal of English for Academic Purposes, 7(2), 15-26.

Nesselhauf, N. (2011). Corpus Linguistics: A practical Introduction [pdf document]. Retrieved from Retrieved from Nesselhauf/files/Corpus\%20Linguistics\%20Practical\%20Introduction .pdf. 
Shaw, P. (2004). How Do We Recognize Implicit Evaluation in Academic Book Reviews? In G. Camiciotti \& E. Bonelli (Eds.). Academic Discourse: New Insights into Evaluation, 121-140.

Swales, J. M., \& Feak, C. B. (2004). Academic writing for graduate students: Essential tasks and skills. Ann Arbor, Mich: University of Michigan Press.

Teubert, W. (2005). My Version of Corpus Linguistics. International Journal of Corpus Linguistics, 10(1), 1-13.

Tognini-Bonelli, E. (2001). Corpus Linguistics at Work (Vol. 6). Amsterdam/ Philadelphia: John Benja.

Wiliss, W. (1997). Hedging in Expert-language Reviews. In R. Markkanen \& H. Schoroder (Eds.), Hedging in Discourse: Approaches to the Analysis of a Pragmatic Phenomenon in Academic Texts, 134-147.

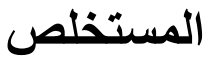

يعهد البحث الى دراسة وتحليل المجال المهمل نسبيًا لعرض وتحليل الكتب الأكاديمية. ويعتمد الجزء

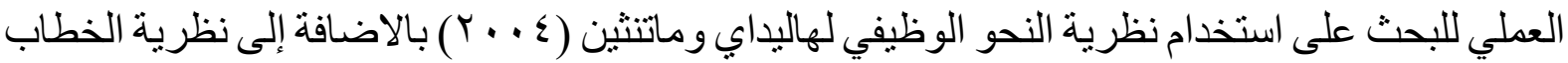

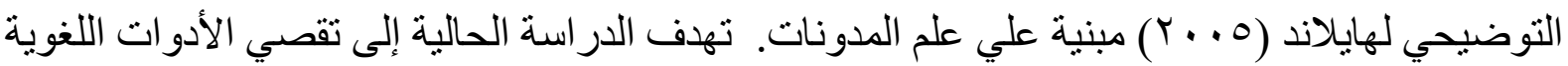

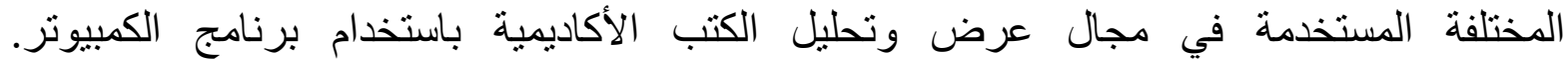

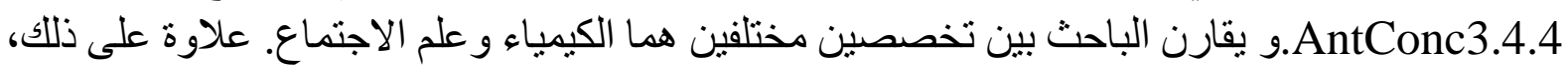

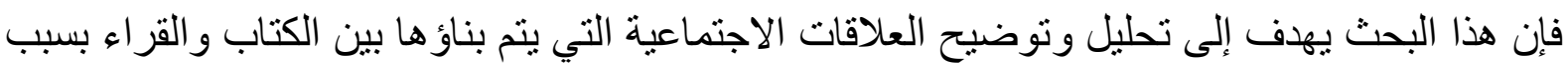

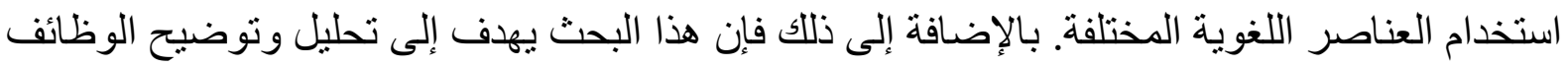

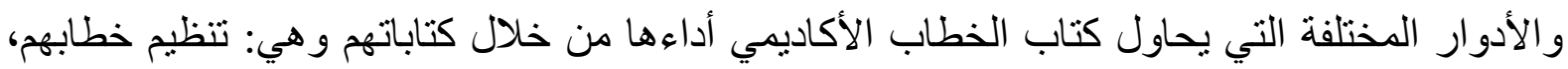
و إنثر الك قر ائهم، ونقل موقفهز.

الكلمات المفتاحية: نظرية الخطاب التوضيحي لهايلاند ـعلم المدونات ـنظرية النحو الوظيفي لهاليداي وماتثثين-عرض وتحليل الكتب الأكاديمية 